\title{
Composition of essential oil and allelopathic activity of aromatic water of Aster lanceolatus Willd. (Asteraceae)
}

\author{
Josiane de Fátima Gaspari Dias ${ }^{1 *}$, Obdúlio Gomes Miguel $^{1}$, Marilis Dallarmi Miguel² \\ ${ }^{1}$ Department of Pharmacy, Laboratory of Phytochemistry, Federal University of Paraná, \\ ${ }^{2}$ Department of Pharmacy, Laboratory of Pharmacotechnique, Federal University of Paraná
}

\begin{abstract}
The essential oil obtained from flowers of Aster lanceolatus was submitted the CG-MS and presented as result thirteen substances with largest concentration; among them, the caryophyllene oxide with the larger one. The aromatic water obtained during the extraction process of this essential oil was forwarded to allelopathic test, and demonstrated to be capable to inhibit the germination and growth of Lactuca sativa.
\end{abstract}

Uniterms: Essential oil. Aster lanceolatus. Caryuphyllene oxide. Aromatic water. Allelopathy.

O óleo essencial obtido das flores de Aster lanceolatus foi submetido a CG-EM e apresentou como resultado treze substâncias, entre elas o óxido de cariofileno com a maior concentração. A água aromática obtida durante o processo de extração do óleo essencial foi encaminhada para teste alelopático, a qual demonstrou ser capaz de inibir a germinação e crescimento de Lactuca sativa.

Unitermos: Óleo Essencial. Aster lanceolatus. Óxido de cariofileno. Água aromática. Alelopatia.

\section{INTRODUCTION}

The Asteraceae family compasses the largest family of angiosperms with approximately 23,000 species, 1,535 genera and represents approximately $10 \%$ of all world flora (Nakajima, Semir, 2001). The plants of Asteraceae family are studied respecting their chemical composition and biological activity (Verdi, Brighente, Pizzolatti, 2005) presenting varied constituents, between them essential oils (Cronquist, 1981) that could present as commercial importance for perfumes and liquors industry (Costa, Doni Filho, 2002, Agostini et al., 2005) as pharmacological importance due to diverse biological activities: nematicide, genotoxic, larvicide, antispasmodic (Gazim et al., 2007), modulation for macrophages activation (Lopes et al., 2005), antimicrobial (Ferronatto et al., 2007, Bozin et al., 2008), antifungal (Gazim et al., 2008) and allelopathic (Verdi, Brighente, Pizzolatti, 2005).

The genus Aster presents varied compounds, between them, flavones, saponines, sugars and esters in $A$.

\footnotetext{
*Correpondence: J. F. G. Dias. Department of Pharmaceutics, Laboratory of Phytochemistry, Federal University of Paraná, Av. Prefeito Lothário Meissner, n.3400 - Jardim Botânico, 80210-170 - Curitiba - PR, Brasil. E-mail: jodias@pop.com.br
}

ageratoides (Cheng et al., 1993); saponines in A. batangensis and A. lingulatus (Shao et al., 1995a, Shao et al., 1995b, Shao et al.,1995c, Shao et al., 1997a, Shao, Ho and Chin, 1997); coumarins in A. praealtus (Wilzer et al., 1989); 3,5-dicaffeoyl-muсo-quinic in A. scaber (Kwon et al., 2000); cyclic pentapeptides (Morita et al., 1993), monoterpenic and triterpenic glicosides (Cheng, Shao, 1994), oligopeptides (Cheng et al., 1994), acyclic peptide (Morita et al., 1995) and pentapeptides (Cheng et al., 1996) in Aster tataricus.

Known popularly as margarida-de-são-miguel, panicled aster and monte cassino, Aster lanceolatus is a cutting species (Ferronato, 2000) that presents extracts with antibacterial activity against Streptococcus pyogenes, Salmonella typhimurium, Staphylococcus aureus (Dias et al., 2005a, 2006), antifungal activity against Fusarium oxysporum and Cylindrocladium spathulatum (Dias et al., 2006) and allelopathic influence on the germination and growth of Lactuca sativa (Dias, Miguel, Miguel, 2007).

Many definitions were already presented for allelopathy, however, the definition accepted by the International Society of Allelopathy mentions allelopathy as a science that studies any process involving, mainly, secondary 
metabolites produced by plants, algae, bacteria and fungi, which influences the growth of biological systems with positive or negative effects (Pinto et al., 2002).

In this perspective, this work had the purpose to identify the essential oil composition by means of gas chromatography and evaluate the allelopathic activity of aromatic water from $A$. lanceolatus.

\section{MATERIAL AND METHODS}

A. lanceolatus was collected in the month of June/2003 at Holambra, state of São Paulo. The exsiccates were identified by the botanist Dr. Gerdt Hatchbach of Municipal Botanical Museum (Museu Botânico Municipal - MBM) of Curitiba, state of Paraná, and recorded in this museum under the number 287.063.

Utilizing hydrodistillation, $100 \mathrm{~g}$ of flowers were submitted to a "Clevenger" type apparatus for six hours, being obtained essential oil and aromatic water. The essential oil was analyzed by CG-MS $(0.2 \mathrm{~mL}$ of oil being solubilized in $1 \mathrm{~mL}$ of methanol) utilizing an Agilent ${ }^{\circledR}$ 6890 gas chromatograph equipped with a HP-5 column (5\% phenyl and $95 \%$ polydimethylsiloxane) with $0.25 \mathrm{~mm}$ of internal diameter and $15 \mathrm{~cm}$ of length, and an Agilent ${ }^{\circledR}$ 5973 mass spectrometer. Utilizing helium as carrier gas $(0.8 \mathrm{~mL}$ per minute), the utilized temperature gradient was: initial temperature $40{ }^{\circ} \mathrm{C}$ with landing of 2 minutes and heating slope at $10{ }^{\circ} \mathrm{C}$ per minute up to $250{ }^{\circ} \mathrm{C}$ with landing of 20 minutes. The injector temperature was of $250{ }^{\circ} \mathrm{C}$ and the detector temperature of $280{ }^{\circ} \mathrm{C}$. The volume of injection was of $20 \mu \mathrm{L}$ with split of 100:1. The identification of constituents of essential oil was done by comparison of mass spectrum of referred constituent, with the existing spectra in the equipment databank (Mass Spectral Database NIST 98).

The aromatic water was forwarded to allelopathic assay utilizing the technique described by Macías, Castellano, Molinillo, 2000; Chon et al., 2005; Dias et al., 2005b with some modifications: the aromatic water was not taken to stove at $60{ }^{\circ} \mathrm{C}$ for 24 hours, but utilized directly on filter paper, being excluded, therefore, the use of distilled water to humidify the filter paper. The control utilized was distilled water under the same conditions as those of the assay. According to Farmacopéia (1988), aromatic water is the saturated solution of essential oil, therefore, the utilization of aromatic water had the purpose to establish the existing relationship between entre the essential oil constituents and the allelopathic activity. For statistical analysis it was employed the program SISVAR (Ferreira, 2000). The verification of differences of statistically significant averages was developed by means of
Scott-Knott test with 5\% of probability. The Scott-Knott test was chosen because it is clear, objective and exempted of ambiguities (commonly present in the majority of tests of multiple comparisons). The treatment was considered effective when all the repetitions were within the same group of averages.

\section{RESULTS AND DISCUSSION}

In $100 \mathrm{~g}$ of flowers of A. lanceolatus, it was obtained $0.2 \%$ of essential oil $(\mathrm{w} / \mathrm{v})$ and $5 \mathrm{~mL}$ of aromatic water.

The chromatogram evaluation has revealed the presence of thirteen substances (Table I), out of which the caryophyllene oxide (Figure 1) presented the higher concentration. At Figure 2, it is possible to visualize the mass spectrum comparison of caryophyllene oxide present in the sample, with the spectrum appearing at NIST Library and the peak of molecular ion in $\mathrm{m} / \mathrm{z} 220$, indicative of caryophyllene oxide structure (Moreira et al., 2007).

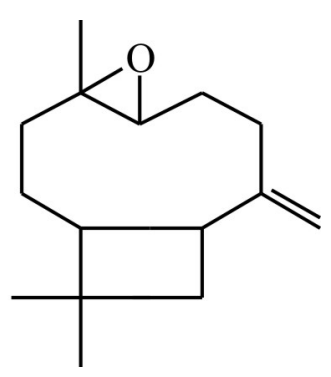

FIGURE 1 - Chemical structure of caryophyllene oxide (Sousa et al., 2006)

The caryophyllene oxide is a sesquiterpen present in essential oil of Ageratum conyzoides (known as wild mint) (Castro et al., 2004), Calyptranthes concinna, Calyptranthes lucida and Calyptranthes rubella (Limberger et al., 2002), Piper arboreum (Mesquita et al., 2005), Cinnamomun zeylanicum (Lima et al., 2005), Baccharis articulata, Baccharis cognata, Baccharis uncinella, Baccharis milleflora (Agostini et al., 2005) propolis (Sousa et al., 2006; Torres et al., 2008), Chamomilla recutita (Borsato et al., 2007), Calendula officinalis (Gazim et al., 2007), Copaifera langsdorffii (Lima Neto, Gramosa, Silveira, 2008), Duguetia furfuracea (Valter et al., 2008) with antibacterial activity against Staphylococcus aureus (Ulubelen et al., 1994) and anticarcinogenic activity (Sousa et al., 2006)

The results of allelopathic assay have demonstrated statistically significant difference between the germination of L. sativa with aromatic water and with distilled water, indicating inhibition of germination (Table II). In 
TABLE I - Constituents of essential oil of A. lanceolatus

\begin{tabular}{|c|c|c|c|}
\hline PEAK & RETENTION TIME (min) & $\operatorname{AREA}(\%)$ & NAME OF CONSTITUENT \\
\hline 1 & 8.27 & 2.58 & Mirtenol \\
\hline 2 & 12.37 & 1.76 & $\alpha$-Murolen \\
\hline 3 & 12.94 & 3.47 & Naphthalene, 1,2-dihydro-1,1,6-trimethyl \\
\hline 4 & 13.08 & 7.36 & Bisabolene \\
\hline 5 & 13.26 & 1.51 & $\beta$-Ionone \\
\hline 6 & 13.40 & 4.11 & Spatulenol \\
\hline 7 & 13.47 & 34.53 & Caryophyllene oxide \\
\hline 8 & 13.77 & 12.72 & 3-Cyclohexene-1-carboxaldehyde, 3,4 \\
\hline 9 & 13.96 & 3.71 & Cedren-13-ol, 8 \\
\hline 10 & 14.22 & 2.48 & Neoclovene-(I), dihydro \\
\hline 11 & 14.50 & 1.94 & Azulene, 1-4-dimethyl-7-(1-methyl) \\
\hline 12 & 14.56 & 1.53 & $\begin{array}{l}\text { 2H-Benzocyclohepten-2-one, } \\
1,4 \mathrm{a}, 5,6,7,8,9,9 \mathrm{a} \text {-octahydro } 4 \text { a methyl, trans }\end{array}$ \\
\hline 13 & 16.15 & 5.19 & 1, hexahydrofarnesyl acetone \\
\hline
\end{tabular}

NOTA: Data obtained by means of comparison to equipment databank (Database/NIST 98).

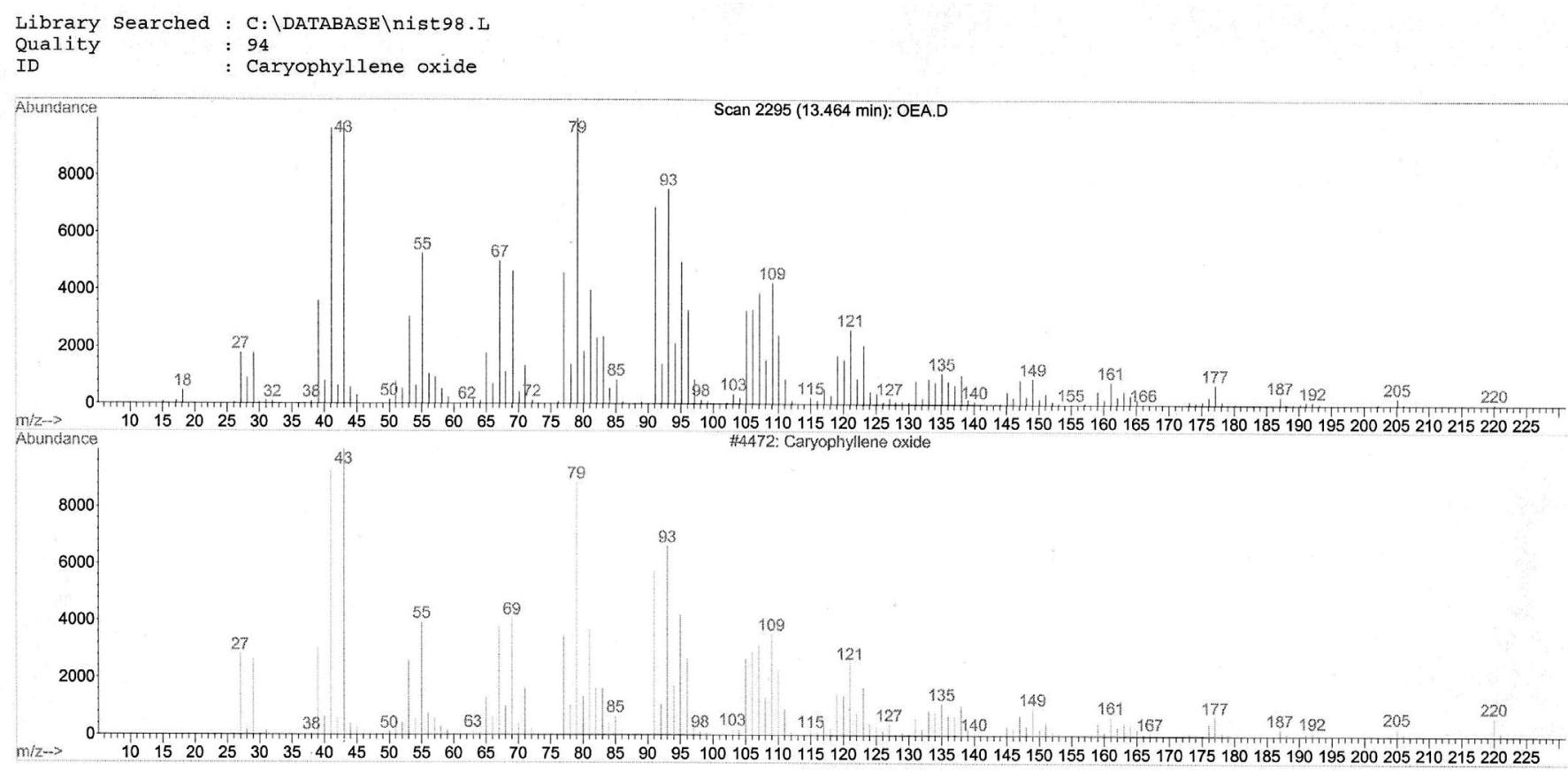

FIGURE 2 - Mass spectrum of caryophyllene oxide.

the growth assay it was observed that the radicles of $L$. sativa did not suffer influence of aromatic water from A. lanceolatus, but, the hypocotyls have suffered such inhibition (Table II).

When evaluating the growth, it is known that it results from the germination. The hypocotyl and the radicle are originated from the embryonic axis, a vital part of seed containing meristematic tissue in both of its two extremities, with growth conditions for both directions, that of the roots (radicle) and the stalk one (hypocotyl), originating a plantule with fixation conditions to soil and ability to photosynthesize necessary substances (Carvalho, Nakagawa, 
TABLE II - Evaluation of allelopathic activity of aromatic water from A. lanceolatus

\begin{tabular}{|c|c|c|c|c|c|}
\hline \multicolumn{6}{|c|}{ GERMINATION -Scott-Knott Test $(P<0.05)$} \\
\hline \multicolumn{2}{|c|}{ SAMPLE } & \multicolumn{4}{|c|}{ GVI (GERMINATION VELOCITY INDEX) } \\
\hline Aro & & \multicolumn{4}{|c|}{$3.6625 \mathrm{a}$} \\
\hline \multirow{2}{*}{\multicolumn{2}{|c|}{ Control }} & \multicolumn{4}{|c|}{$7.5425 \mathrm{~b}$} \\
\hline & & \multicolumn{4}{|c|}{ GROWTH - Scott Knott Test $(P<0.05)$} \\
\hline \multicolumn{3}{|c|}{ Radicle } & \multicolumn{3}{|c|}{ Hypocotyl } \\
\hline Treatment & Repetition & Average $(\mathrm{mm})$ & Treatment & Repetition & Average $(\mathrm{mm})$ \\
\hline Aromatic water & 1 & $16.9 \mathrm{a}$ & Aromatic water & 1 & $10.3 \mathrm{a}$ \\
\hline Aromatic water & 2 & $7.9 \mathrm{a}$ & Aromatic water & 2 & $8.2 \mathrm{a}$ \\
\hline Aromatic water & 3 & $13.2 \mathrm{a}$ & Aromatic water & 3 & $10.7 \mathrm{a}$ \\
\hline Aromatic water & 4 & $19.9 \mathrm{a}$ & Aromatic water & 4 & $13.8 \mathrm{a}$ \\
\hline Control & 1 & $20.6 \mathrm{a}$ & Control & 1 & $22.4 \mathrm{~b}$ \\
\hline Control & 2 & $23.6 \mathrm{a}$ & Control & 2 & $29.8 \mathrm{~b}$ \\
\hline Control & 3 & $21.2 \mathrm{a}$ & Control & 3 & $20.6 \mathrm{~b}$ \\
\hline Control & 4 & $24.2 \mathrm{a}$ & Control & 4 & $28.4 \mathrm{~b}$ \\
\hline
\end{tabular}

*Averages followed by the same letter in the same column, do not statistically differ between each other.

1983). The growth of embryonic axis results from its cells increase of and multiplication by means of mitotic divisions (Carvalho, Nakagawa, 1988), therefore, plantules with lower rates of growth present lower incorporation of tissues' reserve supplies by the embryonic axis, thanks to their lower transformation and reserve supplying capacities (Krzyzanowski, Vieira, França Neto, 1999). In this perspective, alterations occurred in the hypocotyl growth of L. sativa could be originated by germination or processes involved in the phase of embryonic axis growth, justifying so the utilization of growth and germination assays.

It is concluded, therefore, that the essential oil of $A$. lanceolatus possesses in its composition, a higher concentration of caryophyllene oxide, which is present in different vegetable species and possesses biological activities. The aromatic water obtained during the process of extraction of essential oil, presented significant allelopathic property, which is already enough to induce abnormal development of plantules of $L$. sativa. The results here in presented indicate the biotechnological potential of the species.

New assays with aromatic water should be developed with the purpose to verify its composition and the presence of caryophyllene oxide, establishing with reasonable sureness the allelopathic influence of caryophyllene oxide.

\section{REFERENCES}

AGOSTINI, F.; SANTOS, A.C.A.; ROSSATO, M.; PANSERA, M.R.; ZATTERA,F.; WASUM, R.; SERAFINI, L.A. Estudo do óleo essencial de algumas espécies do gênero Baccharis (Asteraceae) do sul do Brasil. Rev. Bras. Farmacogn., v.15, n.3, p.215-220, 2005.

BORSATO, A.V.; DONI-FILHO, L.; CÔCCO, L.C.; PAGLIA, E.C. Rendimento e composição química do óleo essencial da camomila [Chamomilla recutita (L.) Rauschert] submetida à secagem à $70^{\circ} \mathrm{C}$. Semina, Ciênc. Agrár., v.28, n.4, p.635-644, 2007.

BOZIN, B.; MIMICA-DUKIC, N.; BOGAVAC, M.; SUVAJDZIC, L.; SIMIN, N.; SAMOJLIK, I.; COULADIS, M. Chemical composition, antioxidant and antibacterial properties of Achillea collina Becker ex Heimerl s.I. and A. pannonica Scheele essential oils. Molecules, v.13, n.9, p.2058-2068, 2008.

CARVALHO, N. M.; NAKAGAWA, J. Sementes: ciência, tecnologia e produção. Campinas: Fundação Cargill, 1983. p. 49.

CARVALHO, N. M.; NAKAGAWA, J. Sementes: ciência, tecnologia e produção. Campinas: Fundação Cargill, 1988. p. $97-101,127$. 
CASTRO, H.G.; OLIVEIRA, L.O.; BARBOSA, L.C.; FERREIRA, F.A.; SILVA, D.J.H.; MOSQUIM, P.R.; NASCIMENTO, E.A. Teor e composição do óleo essencial de cinco acessos de mantrasto. Quim. Nova, v.27, n.1, p.55-57, 2004.

CHENG, D-L.; CAO, X-P.; WEI, H-X.; HE, L. Kaurane diterpenoids from Aster ageratoides. Phytochemistry, v.33, n.5, p.1181-1183, 1993.

CHENG, D.; SHAO, Y. Terpenoid glicosides from the roots of Aster tataricus. Phytochemistry, v. 35, n.1, p. 173-176, 1994.

CHENG, D.; SHAO, Y., HARTMANN, R.; RODER, E.; ZHAO, K. Oligopeptides from Aster tataricus. Phytochemistry, v.36, n.4, p.945-948, 1994.

CHENG, D.; SHAO, Y.; HARTMANN, R.; ROEDER, E.; ZHAO, K. New pentapeptides from Aster tataricus. Phytochemistry, v.41, n.1, p.225-227, 1996.

CHON, S-U; JANG, H-G; KIM, D-K; KIM, Y-M; BOO, H-O; KIM, Y-J. Allelopathic potential in lettuce (Lactuca sativa) plants. Sci. Hortic., v.106, n.3, p.309-317, 2005.

COSTA, M.A.D.; DONI FILHO, L. Aspectos do processo de produção agrícola na cultura da camomila [Chamomilla recutita (L.) Rauschert] no município de Mandirituba, Paraná. Visão Acad., v.3, n.1, p.49-56, 2002.

CRONQUIST, A. An integrated system of classification of floring plants. New York: Columbia University Press, 1981. p.1021-1028.

DIAS, J.F.G.; VIRTUOSO, S.; DAVET, A.; CUNICO, M.M.; FERRONATO, M.L.; BUFFON, M.C.M.; MIGUEL, M.D.; MIGUEL, O.G. Avaliação do efeito do extrato etanólico de Aster lanceolatus Willd. (Asteraceae) no controle do crescimento das bactérias da placa dentária. Estudo "in vitro". Visão Acad., v.6, n.2, p.20-23, 2005a.

DIAS, J.F.G.; CIRIO, G.M.; MIGUEL, M.D.; MIGUEL, O.G. Contribuição ao estudo alelopático de Maytenus ilicifolia Mart. Ex Reiss., Celastraceae. Rev. Bras. Farmacogn., v.15, n.3, p.220-223, 2005 b.

DIAS, J.F.G.; VIRTUOSO, S.; DAVET, A.; CUNICO, M.M.; MIGUEL, M.D.; MIGUEL, O.G.; AUER, C.G.; GRIGOLETTI-JUNIOR, A.; OLIVEIRA, A.B.; FERRONATO, M.L. Atividade antibacteriana e antifúngica de extratos etanólicos de Aster lanceolatus Willd., Asteraceae. Rev. Bras. Farmacogn., v.16, n.3, p.83-87, 2006.
DIAS, J.F.G.; MIGUEL, O.G.; MIGUEL, M.D. Cromatografia gasosa e avaliação da atividade alelopática das frações hexano, diclorometano e acetato de etila de Aster lanceolatus Willd. (Asteraceae). Visão Acad., v.8, n.2, p.11-19, 2007.

FARMACOPÉIA Brasileira. 4. ed. São Paulo: Atheneu, 1988.

FERREIRA, D.F. Sistema de análise de variância de dados balanceados (SISVAR). 2000. Pacote computacional. Lavras: UFLA.

FERRONATO, M.L. Aprimoramento de atributos comercialmente desejáveis em Aster sp cultivar White Master através do uso de reguladores do crescimento vegetal. Curitiba, 2000. 80 p. [Dissertação de Mestrado em Agronomia. Setor de Ciências Agrárias. Universidade Federal do Paraná].

FERRONATTO, R; MARCHESAN, E.D.; PEZENTI, E.; BEDNARSKI, F.; ONOFRE, S.B. Atividade antimicrobiana de óleos essenciais produzidos por Baccharis dracunlifolia D.C. e Baccharis uncinella D.C. (Asteraceae). Rev. Bras. Farmacogn., v.17, n.2, p.224-230, 2007.

GAZIM, Z.C.; FERREIRA, G.A.; REZENDE, C.M.; NAKAMURA, C.V.; DIAS FILHO, B.P.; CORTEZ, D.A.G. Identificação dos constituintes químicos da fração volátil da Calendula officinalis produzida no Paraná. Hortic. Bras., v.25, n.1, p.118-121, 2007.

GAZIM, Z.C.; REZENDE, C.M.; FRAGA, S.R.; SVIDZINSKI, T.I.E.; CORTEZ, D.A.G. Antifungal activity of the essential oil from Calendula officinalis L. (Asteraceae) growing in Brazil. Braz. J. Microbiol., v.39, n.1, p.61-63, 2008.

KRZYZANOWSKI, F.C.; VIEIRA, R.D.; FRANÇA NETO, J.B. Vigor de sementes: conceitos e testes. Londrina: ABRATES, 1999. 218p.

KWON, H.C.; JUNG, C.M.; SHIN, C.G.; LEE, J.K.; CHOI, S.U.; KIM, S.Y.; LEE, K.R. A new caffeoyl quinic acid from Aster scaber and its inhibitory activity against human immunodeficiency virus-1 (HIV-1) Integrase. Chem. Pharm. Bull., v.48, n.11, p.1796-1798, 2000.

LIMA, M.P.; ZOGHBI, M.G.B.; ANDRADE, E.H.A.; SILVA, T.M.D.; FERNANDES, C.S. Constituintes voláteis das folhas e dos galhos de Cinnamomun zeylanicum Blume (Lauraceae). Acta Amazon., v.35, n.3, p.363-366, 2005. 
LIMA NETO, J.S.; GRAMOSA, N.V.; SILVEIRA, E.R. Constituintes químicos dos frutos de Copaifera langsdorffii Desf. Quim. Nova, v.31, n.5, p.1078-1080, 2008.

LIMBERGER, R.P.; SIMÕES-PIRES, C.A.; SOBRAL, M.; MENUT, C.; BESSIERE, J-L.; HENRIQUES, A.T. Essential oils from Calyptranthes concinna, C. lucida, $C$. rubella (Mytaceae). Rev. Bras. Ciênc. Farm., v.38, n.3, p.355-360, 2002.

LOPES, F.C.M.; BENZATTI, F.P.; JORDÃO JUNIOR, C.M.; MOREIRA, R.R.D.; CARLOS, I.A. Effect of the essential oil of Achillea millefolium L. In the production of hydrogen peroxide and tumor necrosis factor- $\alpha$ in murine macrophages. Rev. Bras. Ciênc. Farmac., v.41, n.3, p.401405, 2005.

MACÍAS, F.A.; CASTELLANO, D.; MOLINILLO, J.M.G. Search for a standard phytotoxic biossay for allelochemicals. Selection of standard target species. J. Agric. Food Chem., v.48, n.6, p.2512-2521, 2000.

MESQUITA, J.M.O.; CAVALEIRO, C.; CUNHA, A.P.; LOMBARDI, J.A.; OLIVEIRA, A.B. Estudo comparativo dos óleos voláteis de algumas espécies de Piperaceae. Rev. Bras. Farmacogn., v.15, n.1, p.6-12, 2005.

MOREIRA, I.S.; ROQUE, N.F.; CONTINI, K.; LAGO, J.H.G. Sesquiterpenos e hidrocarbonetos dos frutos de Xylopia emarginata (Annonaceae). Rev. Bras. Farmacogn., v.17, n.1, p.55-58, 2007.

MORITA, H.; NAGASHIMA, S.; TAKEYA, K.; ITOKAWA, H. Astins A and B, antitumor cyclic pentapeptides from Aster tataricus. Chem. Pharm. Bull., v.41, n.5, p.992-993, 1993.

MORITA, H.; NAGASHIMA, S.; TAKEYA, K.; ITOKAWA, H. Structure of a new peptide, astin J, from Aster tataricus. Chem. Pharm. Bull., v.43, n.2, p.271-273, 1995.

NAKAJIMA, J.N.; SEMIR, J. Asteraceae do Parque Nacional da Serra da Canastra, Minas Gerais, Brasil. Rev. Bras. Bot., v.24, n.4, p.471-478, 2001.

PINTO, A.C.; SILVA, D.H.S.; BOLZANI, V.S.; LOPES, N.P.; EPIFANIO, R.A. Produtos naturais: atualidade, desafios e perspectivas. Quim. Nova, v.25, n.1, p.45-61, 2002.

SHAO, Y.; ZHOU, B.; MA,.K.;WU, H.; LIN, L.; CORDELL, G.A. Medicagenic acid saponins from Aster batangensis. Phytochemistry, v.39, n.4, p.875-881, 1995a.
SHAO, Y.; ZHOU, B-N.; LIN, L-Z.; CORDELL, G.A. Triterpenoid saponins from Aster batangensis. Phytochemistry, v.38, n.4, p.927-933, 1995 b.

SHAO, Y.; ZHOU, B-N.; MA, K.; WU, H-M. New triterpenoid saponina, asterbatanoside D and E, from Aster batangensis. Planta Med., v.61, n.3, p.246-249, 1995c.

SHAO, Y.; HO, C-T.; CHIN, C-K.; ROSEN, R.T.; HU, B.; QIN, G-W. Triterpenoid saponins from Aster lingulatus. Phytochemistry, v. 44, n.2, p.337-340, 1997.

SHAO, Y.; HO, C-T.; CHIN, C-K. Asterlingulatosides C and D, cytotoxic triterpenoid saponins from Aster lingulatus. J. Nat. Prod., v.60, n.7, p.743-746, 1997.

SOUSA, S.A.A.; CITÓ, A.M.G.L.; LOPES, J.A.D. Constituintes do óleo essencial da propólis produzida na cidade de Pio IX - Piauí. Rev. Bras. Plantas Med., v.8, n.4, p.1-3, 2006.

TORRES, R.N.S.; LOPES, J.A.D.; MOITA NETO, J.M.; CITÓ, A.M.G.L. Constiuintes voláteis de própolis piauiense. Quím. Nova, v.31, n.3, p. 479-485, 2008.

ULUBELEN, A.; ÖKSUZ, S.; KOLAK, U.; BOZOKJOHANSSON, C.; CELIK, C.; VOELTER, W. Antibacterial diterpenes from roots of Salvia viridis. Planta Med., v.66, n.5, p.458-462, 2000.

VALTER, J.L.; ALENCAR, K.M.C.; SARTORI, A.L.B.; NASCIMENTO, E.A.; CHANG, R.; MORAIS, S.A.L.; LAURA, V.A.; YOSHIDA, N.C.; CAROLLO, C.A.; SILVA, D.B.; GRASSI, R.F.; FABRI, J.R.; SIQUEIRA, J.M. Variação química no óleo essencial das folhas de seis indivíduos de Duguetia furfuracea (Annonaceae). Rev. Bras. Farmacogn., v.18, n.3, p.373-378, 2008.

VERDI, L.G.; BRIGHENTE, I.M.C.; PIZZOLATTI, M.G. Gênero Baccharis (Asteraceae): aspectos químicos, econômicos e biológicos. Quim. Nova, v.28, n.1, p.85-94, 2005.

WILZER, K.A.; FRONCZEK, F.R.; URBATSCH, L.E.; FISCHER, N.H. Coumarins from Aster praealtus. Phytochemistry, v.28, n.6, p.1729-1735, 1989.

Received for publication on $18^{\text {th }}$ April 2008 Accepted for publication on $18^{\text {th }}$ March 2009 